\title{
AN EXAMINATION OF ASSURANCE PRACTICES ON TURKISH COMPANIES' GREENHOUSE GAS EMISSIONS DISCLOSURES ${ }^{1}$
}

\author{
DOI: 10.17261/Pressacademia.2020.1180 \\ JEFA- V.7-ISS.1-2020(5)-p.44-53
}

Halil Emre Akbas ${ }^{1}$, Seda Canikli², Semih Yilmazer ${ }^{3}$, Bertac Sakir Sahin ${ }^{4}$

${ }^{1}$ Yildiz Technical University, Department of Business Administration, Istanbul, Turkey. akbase@gmail.com , ORCID ID: 0000-0001-8923-5700

${ }^{2}$ Yildiz Technical University, Department of Business Administration, Istanbul, Turkey. sedacanikli@yahoo.com, ORCID ID: 0000-0001-7523-5822

${ }^{3}$ Yildiz Technical University, Department of Business Administration, Istanbul, Turkey. semihy@yildiz.edu.tr , ORCID ID: 0000-0003-3600-3732

${ }^{4}$ Yildiz Technical University, Research Assistant, Department of Business Administration, Istanbul, Turkey. bertacsa@yildiz.edu.tr , ORCID ID: 0000-0003-0414-5402

\begin{tabular}{ll}
\hline Date Received: January 25, $2020 \quad$ Date Accepted: Mach 23, 2020 \\
\hline
\end{tabular}

To cite this document

Akbas, H. E., Canikli, S., Yilmazer, S., Sahin, B. S.,(2020). An examination of assurance practices on Turkish companies' greenhouse gas emissions disclosures. Journal of Economics, Finance and Accounting (JEFA), V.7(1), p.44-53.

Permemant link to this document: http://doi.org/10.17261/Pressacademia.2020.1180

Copyright: Published by PressAcademia and limited licenced re-use rights only.

\section{ABSTRACT}

Purpose- The aim of this study is to examine the status of assuring practices of GHG disclosures of Turkish companies, using the data available from the Carbon Disclosure Project (CDP) Turkey surveys for the period of 2015-2017. More specifically, it is aimed to determine the number of companies that assured their GHG emission disclosures, the scope of assurance, the types of assurance providers, the assurance level and the standards employed for the assurance of GHG disclosures.

Methodology- The sample of the study is obtained from the CDP Database. In this study, we selected Turkish companies that answered the CDP questionnaire between the years of 2015 and 2017.

Findings- The number of the total submitted CDP reports and the assured reports have an upward trend during the sample period. Nevertheless, it is observed that the number of reports having assurance services increased rapidly in those years. This shows that verified information has been more demanded by stakeholders.

Conclusion- The increasing trend in the number of companies assuring their GHG disclosures presents opportunities for audit firms and other assurance service providers.

Keywords: GHG, assurance, carbon disclosure, climate change, verification.

JEL Codes: G10, M48, M14

\section{INTRODUCTION}

Greenhouse gases, in the atmosphere, perform the function of reflecting some of the sun's rays coming back to the earth (methane gas, carbon dioxide, nitrogen oxide, water vapor, ozone etc.). Thanks to this function of greenhouse gases called "natural greenhouse effect" in the literature, the world has a temperature suitable for living life (Houghton, 2004: 16). The deterioration of the greenhouse gas balance in the atmosphere, especially carbon gas, causes climate change (Ramanathan and Feng, 2009: 37). Climate change refers to "a statistically significant variation in either the mean state of the climate or in its variability, persisting for an extended period" (IUCN, 2011: 18). Both theoreticians and practitioners have been making efforts to diminish the negative effects of global warming. In recent years, research and projects on global warming have started to focus on the corporate sector (Hahn, Reimsbach and Scheimann, 2015: 81). Because the carbon emissions resulting from companies' activities have become one of the most important effects of global warming. Therefore, the environmental performance of the companies is vital for all companies concerned (Bewley and Li, 2000: 202). In this respect, there has been

\footnotetext{
${ }^{1}$ An earlier version of this manuscript was presented at the 10th International Conference on Governance, Fraud, Ethics and Corporate Social Responsibility, Edirne, Turkey, 2019.
} 
an increasing demand from various stakeholder groups such as governments, investors, the media, employees, customers, and the general public, for companies to publicly report information about their climate change-related business practices.

Companies' disclosures about their environmental performance are also important in terms of theories related to voluntary disclosure as well as the struggle against global warming. Disclosures on the environmental performance of companies have a direct relationship with the legitimacy theory. Legitimacy theory is concerned with the extent to which companies act following the expectations of society and law. According to the legitimacy theory, companies should act under the existing "social contract" with society and comply with the norms (Cotter, Lokman and Najah, 2011: 10). Considering the definition of legitimacy theory, environmental disclosures can be used as an instrument to meet the expectations of society (Freedman and Jaggi, 2005). With environmental disclosures, companies prove their legitimacy by exposing that they act by the expectations of their stakeholders (Cotter, Lokman and Najah, 2011: 11). Another important theory related to this issue is stakeholder theory. According to stakeholder theory, businesses should consider the benefits of all stakeholders, not just their shareholders. In this context businesses should pay attention to their stakeholders' sensitivity to climate change and make disclosures (Harrison and Wicks, 2013; Gokten, Marşap and Gokten, 2018: 919). For these reasons, companies prefer to report their GHG disclosures. However, GHG emission reporting is noteworthy only if such reports are perceived as relevant and credible (Chatterjee, 2012). But the ambiguity in the gathering and reporting of emissions results in a requirement for independent assurance to enhance the credibility of reported emissions (Green and Li, 2011).

Reducing GHG emissions is a very long and difficult process. Beside mitigation and adaptation strategies, an important step is to disclose relevant and reliable information about these emissions (Simnett and Nugent, 2007). According to KPMG's recent report, the world's largest companies include their non-financial disclosures in their annual financial reports. The percent of companies that separately report their GHG emissions is 60\%. Additionally, the Global Reporting Initiative (GRI) indicates that $95 \%$ of Global 250 companies are reporting their emissions (KPMG, 2017). The development by GRI and UNCTAD-ISAR has focused attention on the associated issue of assuring these reports. Following the awareness of GHG disclosures and assurance activities, relevant standards have been published: ISAE 3410 Assurance Engagements on Greenhouse Gas Statements and ISO 14064-3 Greenhouse Gases. The importance of assurance on emissions is determined in ISAE 3410, Assurance on a Greenhouse Gas Statement and in Organization for Standardizations. ISAE 3410 recognizes the assurance of GHG and aims to fill the gap on GHG assurance provision disclosures (IAASB, 2015). Besides, ISO 14064 is usually used when GHG reports are assured by external auditors and assurance professions (engineers and scientists). This standard provides requirements and guidelines for the conducting of GHG information validation and verification (Bastianoni, Marchi, Caro, Casprini \& Pulselli, 2014: 98).

Carbon Disclosure Project (CDP) is one of the leading organizations working on disclosures of carbon emissions by organizations. CDP, which established in London in 2000, is a non-profit organization with offices and local partners in 50 countries. CDP analyzes and evaluates the data which is collected from the surveys conducted by firms and shares the disclosure data about carbon emissions in the world (Li, Fu, Chen, Shi, Yang and Li, 2019: 27793). CDP has been operating in Turkey with Sabancı University Corporate Governance since 2010 (Omur Tunc \& Calişkan, 2012: 16). In the last report published by CDP, 66 companies responded questions about climate change and water disclosure (CDP, 2019: 39).

The remainding of the paper is structured as follows: The second section provides a brief historical backround and reviews the literature. The next section outlines data and methodology. The fourth section presents the results and discusses empirical analysis. The last section summarizes the study, concludes the results, and offers suggestions for future studies.

\section{LITERATURE REVIEW AND HISTORICAL BACKGROUND}

In the last decade, with the increasing attention given to the relationship between GHGs and global warming, many academicians and practitioners began to search in the field of sustainability, environmental issues, greenhouse gas emissions, company reports and disclosures, besides, assurance on GHG emission disclosures (Green et.al, 2017; Cohen and Simnett, 2015). According to importance of public confidence in credibility of emissions reporting, assurance has become more remarkable. Rational individuals pursue assurance services to improve the credibility and congruity of information that will be used in decision-making process (Chatterjee, 2012). This importance leaded International Auditing and Assurance Standards Board (IAASB) to release an international standard on assurance engagement (ISAE) 3410; Assurance Engagements on Greenhouse Gas (GHG) Statements in 2012. This standard was written in the context of extant ISAE 3000 and addresses an assurance service in support of reliable reporting for both regulatory and voluntary basis (IAASB, 2020).

According to IAASB, all participants in market demand for reliable GHG emissions information and ISAE 3410 considers these demands as need for transparency, comparability and understanding of the basis for the practitioners' disclosures. This standard "requires practitioners to select procedures appropriate to the circumstances of the limited engagement based on an assessment of risks of material misstatement in order to obtain a meaningful level of assurance" (ISAE, 3410). An 
appropriate balance between demands and concerns of some participants and practitioners would be achieved with this standard. Also International Organization for Standardization (ISO) published an important guideline 14064-3: Specification with guidance for the verification and validation of greenhouse gas statements in 2019. This standard specifies principles and requirements guidance for GHG reporting validations for external auditors, accountants and assurance professions (ISO, 2019). The requirement of 14064-3 describes a process for providing assurance to information users in order to obtain complete, accurate transparent information.

Besides IAASB and ISO, academicians have been searching for a better framework regarding to accuracy of reports and disclosures as well. Many researches indicate that assurance can be determined under the source credibility theory (Kim and Green, 2015; Koonce, 1993). Source credibility theory explains how a decision evaluates the bias from the information that comes from providers. This bias can be raised from factors that impact the potential difference between the providers' report and real situation of nature. (Kim and Green, 2015; Birnbaum and Stegner, 1979). This theory also indicates that information users tend to give much priority to information from trustworthy providers. Sources are supposed to be more credible and trustworthy if they have higher expertise or less bias and perceived trustworthiness of the information providers influences persuasion (Shum et.al, 2009; Pornpitakpan, 2004; Holt, 2012; Brink et.al, 2016).

Another theory related to the disclosed information validation is belief revision theory (Hogarth and Einhorn, 1992). Theory reveals that assessed information makes individuals to consider both information content and trustworthiness of the information source and they are relied on a particular belief much more when they have confidence on their received information (Kim and Green, 2015; Pinsker, 2007). Individuals have difficulties regarding to determine the value of information especially when the information is voluntary and contains personal opinions. According to this perception, belief revision theory states that individuals anchor their beliefs to trustworthiness and accurate information.

In previous studies, academicians have searched the disclosed information assurance issue with this background and perceptions. In 2007, Simnett and Nugent stated that great interest on sustainability reports or voluntarily disclosed information assurance arises from requirements of relevance, reliability, comparability and understandability of these reports. By evaluating and analyzing Australian firms' sustainability reports and other reports, authors show how disclosure and assurance trends are becoming important and how society is giving attention to this phenomenon.

Another study investigates country and industry specific factors that impact the advantages of external verification and validation of voluntary GHG disclosures (Chatterjee, 2012). As a starting point, author assumes that, firms operating in a stronger political-economic environment tend to seek external assurance to boost users' confidence in the credibility of their GHG reports. On the contrary, it is expected that demand for external verification is lower in countries with weaker politicaleconomical environments. With an evidence-based content analysis, study investigates 14 multinational firms that operates in eleven different countries, and results supports the assumption of researcher as Guthrie \& Abeysekera, 2006. Additionally, another study found that GHG assurance demand is higher in companies from stakeholder-oriented countries than shareholder-oriented countries (Zhou et al., 2016, Datt et al., 2018).

In 2012, Green and Li investigated the expected gap between GHG emissions assurance settings and perceptions of information sources, assurers and shareholders. Their results show that there is not exist an expected gap between providers and assurers and shareholders. This inference reminds the financial audit expectation gap literature as information providers share users' briefs but not assurers in judgement included areas (Green and Li, 2012; Schelluch and Gay, 2006).

In a recent study, authors discuss that GHG disclosure assurance differs from financial statement assurance in many dimensions but just one similarity; a clear and well defined set of disclosures of measurable parameters (Green et.al, 2017). This similarity guaranteed and defined under law because of well-defined and calculable standard parameters. As in financial statement assurance, also GHG disclosure assurance contains assurers' choice and this choice of assurer is determined by the quality of the assurer. Many searches evaluate the financial audit quality and its aspects in literature (DeAngelo, 1981; Beattie and Fernley, 1995; Kilgore et al.,2014). Besides, assurance quality literature indicates that reputation of assurance firm and capability of partners and staff are important factors in assessing GHG assurance quality (Green and Taylor, 2013; Cohen and Simnett, 2013; Zhou et al., 2013). With a survey instrument and 41 companies that operating in Australia, Green et al. (2017) state that firms make their GHG assurer decisions based on neither their company characteristics nor on those of the assurance firm as a whole. They choose their assurer as a team and team leader with a technical assurance knowledge.

A wide sampled study with 3.008 firms across 43 countries state that carbon-intense industries are more likely to engage in emission assurance services. This interesting and leading study highlights three significant findings regarding to emission assurance. First, increasing number of firms that assure their emission disclosures over time. Second, two distinct groups are suppliers of assurance in emerging markets; audit and assurance services and the second one is specialists. The last finding is 
that assurance reports and statements are not published as a part of sustainability reports anymore. According to authors, there is a growing demand for international assurance standard on emission disclosures (Green and Zhou, 2013).

With this motivational background, this study aims to determine the disclosure assurance trend in an emerging market. We have investigated the growing demand on assurance, assurer type, level of assurance and scope of assurance in Turkey via CDP questionnaires between 2015-2017.

\section{DATA AND METHODOLOGY}

The sample of the study is obtained from CDP Turkey Climate Change Reports. CDP is a not-for-profit organization providing primary information about the environmental impacts of companies, cities, states, and regions through survey questionnaires (CDP,2019). According to the CDP Climate Change Report 2018, 6937 companies responded to the CDP questionnaire in 2018. The report also states that 366 of global 500 companies having the largest market capitalization responded to the questionnaire sent by CDP. Thus, the database not only provides very large and crucial information about carbon emissions of companies but also represents a very large scale of the world economy.

Companies in the CDP surveys are classified according to their status which is submitted, declined to participate, the information provided, no response, and see another. In this study, we have selected Turkish companies that have answered the CDP questionnaire between 2015 and 2017. 2015, 2016, and 2017 years have been chosen since we attempt to examine the yearly change in the assurance of GHG information and preferences of Turkish companies from various aspects related to GHG information.

Table 1: Sample Characteristics

\begin{tabular}{|c|c|c|c|c|c|c|c|c|}
\hline \multicolumn{9}{|c|}{ Panel A-Companies by Years } \\
\hline & \multicolumn{2}{|c|}{ CDP2015 } & \multicolumn{2}{|c|}{ CDP2016 } & \multicolumn{2}{|c|}{ CDP2017 } & \multicolumn{2}{|c|}{ TOTAL } \\
\hline & $\mathrm{N}$ & $\%$ & $\mathrm{~N}$ & $\%$ & $\mathrm{~N}$ & $\%$ & $\mathrm{~N}$ & $\%$ \\
\hline Companies assuring their emissions & 15 & $37 \%$ & 24 & $56 \%$ & 34 & $67 \%$ & 73 & $54 \%$ \\
\hline Companies not assuring their emissions & 26 & $63 \%$ & 19 & $44 \%$ & 17 & $33 \%$ & 62 & $46 \%$ \\
\hline TOTAL & 41 & $100 \%$ & 43 & $100 \%$ & 51 & $100 \%$ & 135 & $100 \%$ \\
\hline \multicolumn{9}{|c|}{ Panel B -Assurance Providers } \\
\hline & \multicolumn{2}{|c|}{ CDP2015 } & \multicolumn{2}{|c|}{ CDP2016 } & \multicolumn{2}{|c|}{ CDP2017 } & \multicolumn{2}{|c|}{ TOTAL } \\
\hline & $\mathrm{N}$ & $\%$ & $\mathrm{~N}$ & $\%$ & $\mathrm{~N}$ & $\%$ & $\mathrm{~N}$ & $\%$ \\
\hline Audit firm provider & 3 & $20 \%$ & 4 & $17 \%$ & 5 & $15 \%$ & 12 & $16 \%$ \\
\hline Specialist provider & 12 & $80 \%$ & 18 & $75 \%$ & 25 & $73 \%$ & 55 & $76 \%$ \\
\hline Provider information not reported & 0 & $0 \%$ & 2 & $8 \%$ & 4 & $12 \%$ & 6 & $8 \%$ \\
\hline TOTAL & 15 & $100 \%$ & 24 & $100 \%$ & 34 & $100 \%$ & 73 & $100 \%$ \\
\hline
\end{tabular}

Analysis in the study provides information relating to the following criteria:

Type of Assurance providers: There are two types of assurance providers; Audit firm provider and specialist provider. Audit firms are traditional audit companies such as Deloitte, PWC, and so on. Specialist providers are organizations that provide certification services and consultancy on environmental issues such as SGS, TSE, and so on.

Scope of Assurance: The study analyzes the scope of assurance into two types; GHG and environmental risk information and standalone GHG information. The scope of assurance information is stated in the assurance report of the audit firm provider or specialist provider.

Level of Assurance: Assurance service levels of companies included in the study are classified into four types high, reasonable, limited, and third party verification/assurance underway.

Assurance Standards: Even though CDP accepts many global assurance standards such as AA1000AS and ISO14064-3 and local standards such as JVETS (Japanese Voluntary Emissions Trading Scheme) Guideline for verification, Korean GHG and energy target management system, and so on, the analyzed companies are assured by two standards which are ISAE3000/3410 and ISO14064-3 standards.

\section{RESULTS AND DISCUSSION}

Panel A of Table 1 reveals both the number and percentage of companies assuring their GHG information have been increasing significantly year by year. The percentages of assured companies are $37 \%, 56 \%$, and $67 \%$ in 2015, 2016, and 2017 
respectively. Figure 1 shows the trend in both total submitted and assured companies in the sample years. According to Figure 1, both the number of the total submitted CDP reports and the assured reports have an upward trend during the sample period. Nevertheless, it is observed that the number of reports having assurance services has increased rapidly in those years.

\section{Figure 1: The Trends of Total Submitted CDP reports and Assurance Provided in the Sample Period}

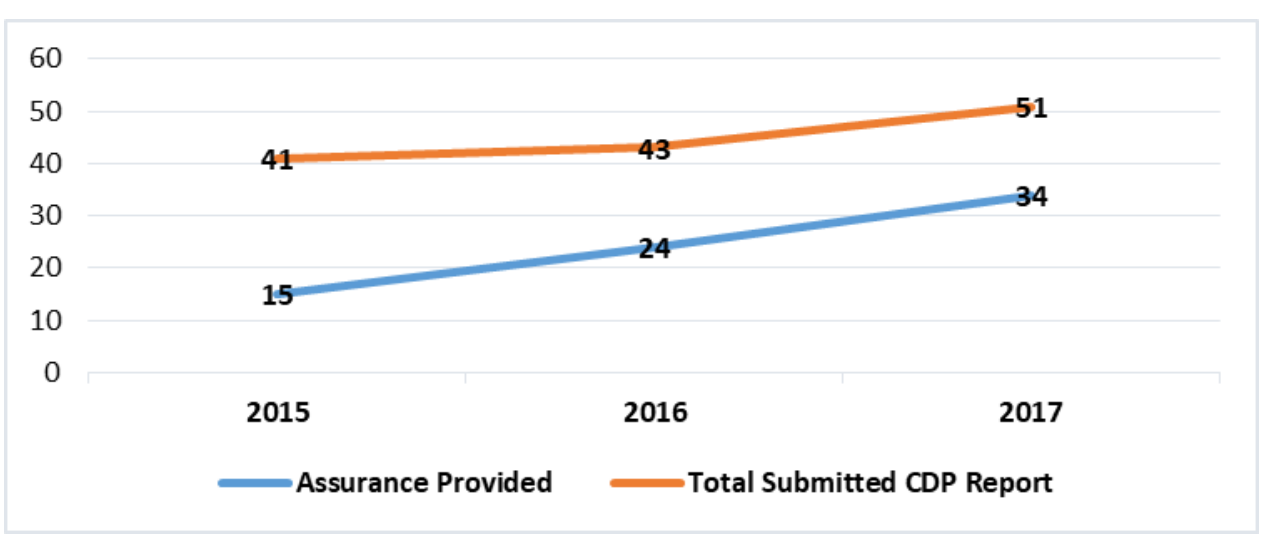

Figure-2 shows that the number of companies not receiving an assurance service has been decreasing while the number of companies assuring their GHG information has been increasing in the sample period. For instance, the number of companies assuring carbon emission information reached two-thirds of the total companies that submitted their CDP reports in 2017. This indicates that verified information has been more demanded by stakeholders.

\section{Figure-2: The Number of Companies Assuring and not Assuring Carbon Emissions}

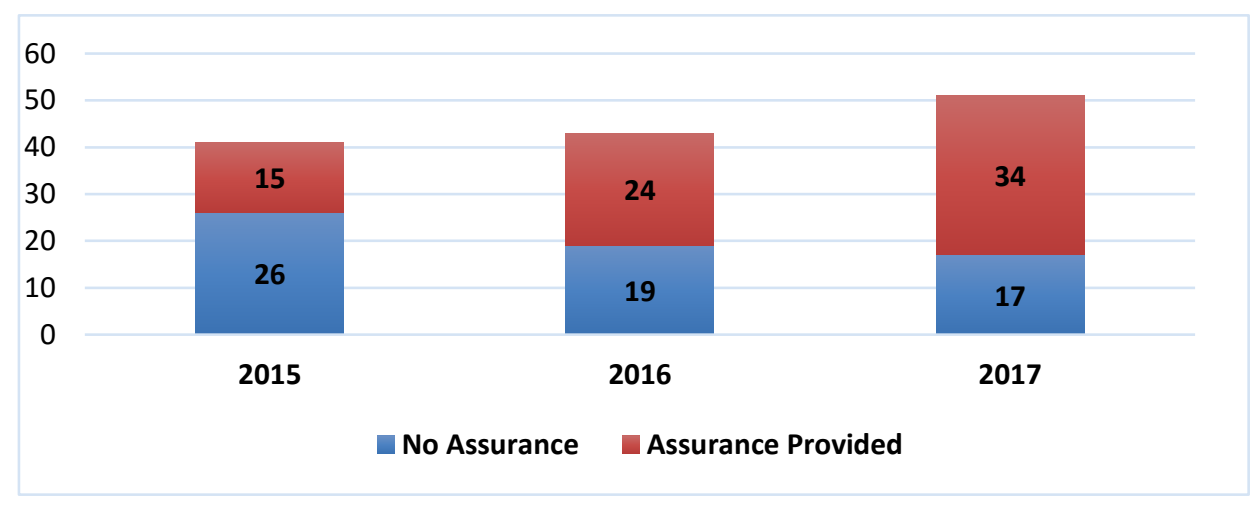

The determinants of the sample of companies performed assurance engagements over the sample years are analyzed below. The determinants included in the study are firm type providing assurance service, the scope of assurance, level of assurance, and the standard used for assurance.

Panel B of Table 1 displays the assurance provider preferences of Turkish companies assuring their carbon emissions. It is seen that specialist providers such as Bureau Veritas, SGS, TSE, RINA are more preferred by Turkish Companies than audit firms such as PWC, Deloitte and so on. Also Figure 3 provides information about preferences of companies on assurance service providers. It is clearly seen the assurance of Turkish companies' carbon emission information is dominated by specialist providers. The underlying reason for this may be the perception that specialist providers have more specialty in environmental issues. 
Figure 3: Type of Firm Providing Assurance Service

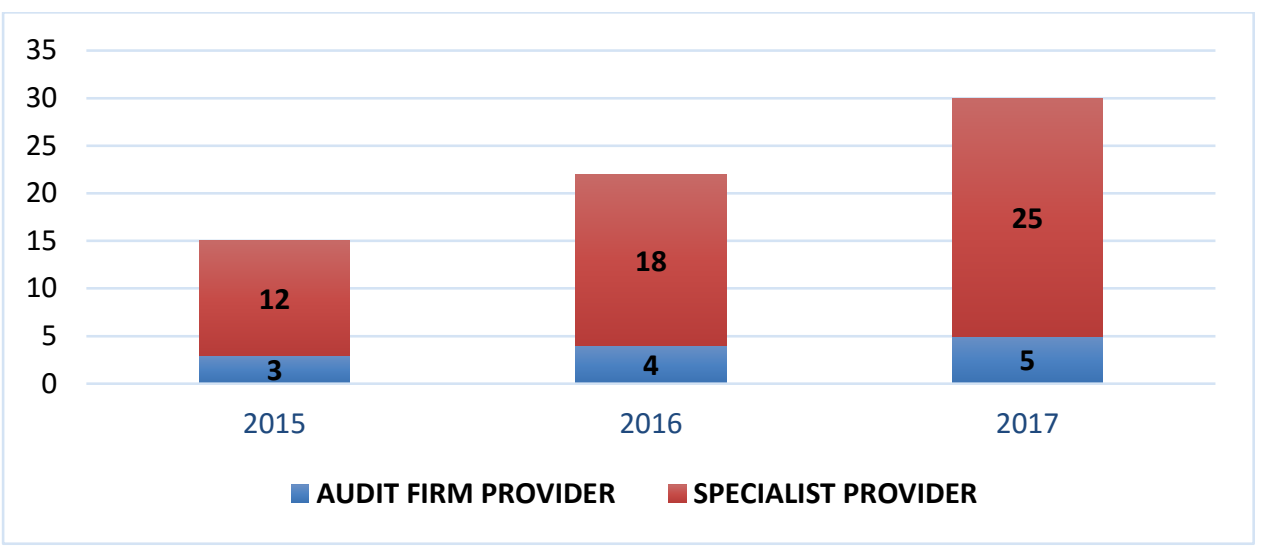

In Figure 4, it is seen that Turkish companies mostly prefer to assure only carbon emissions rather than other environmental risks. It is thought that factors such as cost and difficulties in assuring broader environmental risks affect choices of Turkish companies submitting CDP reports.

\section{Figure 4: Scope of Assurance}

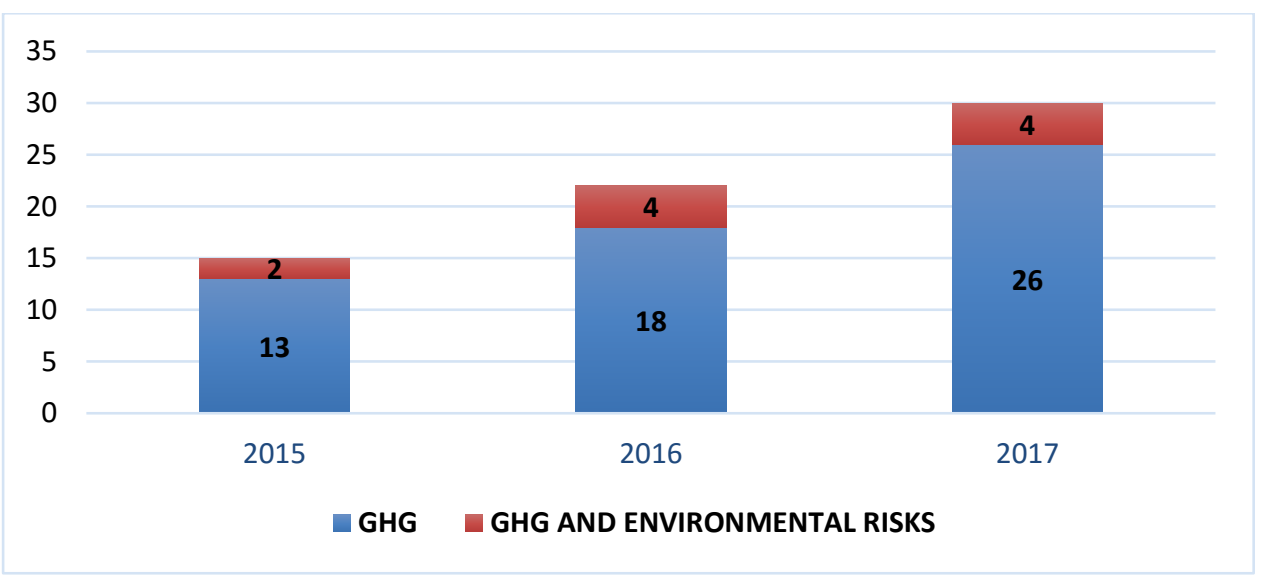

When analyzing the assurance level of sample companies, we determine that most assurance engagements are in the level of reasonable and limited assurance. Figure 5 represents that there is a significant increase in reasonable assurance level in the sample period. In this sense, it can be said that companies are more voluntary to pay more for assurance engagements and assurance providers are being more competent in terms of providing assurance in higher levels. On the other side, the number of high level assurance service is quite low in the sample periods (2015:2, 2016:2 and 2017:2). Furthermore, we observe that the assurance service process has been going on for 2 of the total submitted CDP reports. As seen in Appendix A, reasonable assurance service is provided with the percent of 40, 50, and 59 in 2015, 2016, and 2017 respectively. On the other hand, Limited assurance level constitutes 34, 34 and 29 percent of the reports provided assurance service in 2015, 2016 and 2017, respectively. 
Figure 5: Assurance Levels by Years

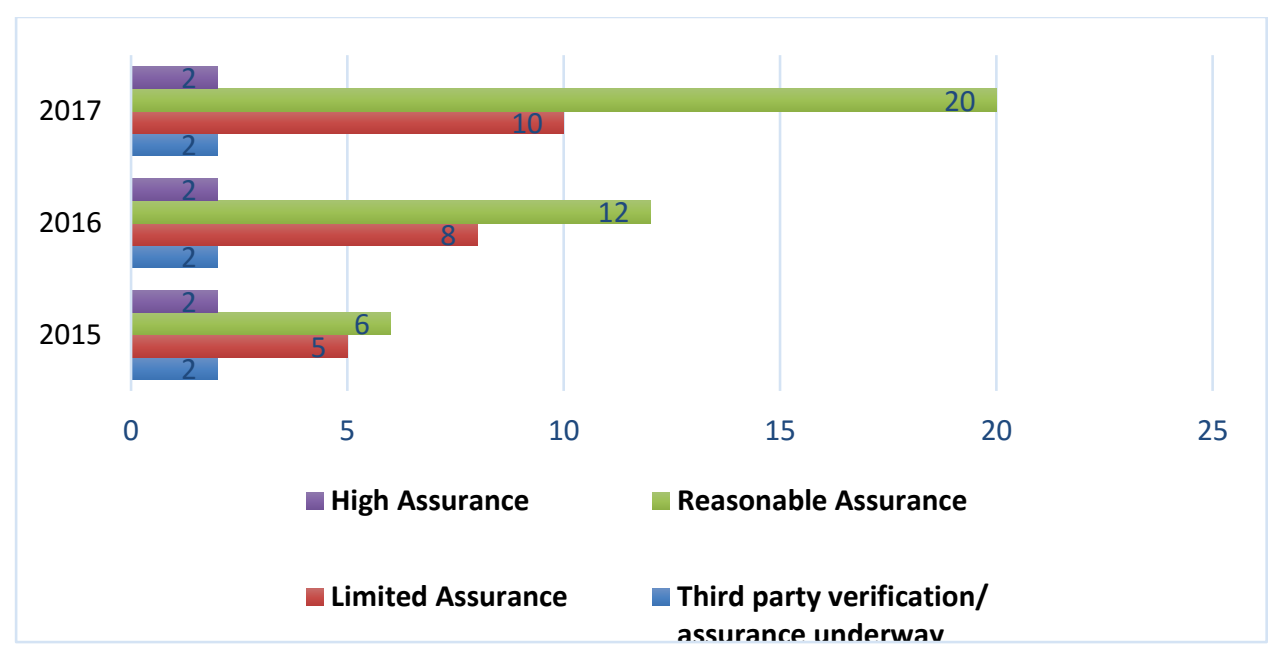

Figure 6 provides some quantitative information about which standards are used when providing assurance service. Accordingly, we can conclude very clearly that the ISO14064-3 standard is predominantly preferred over sample periods since specialist providers provide assurance service with that standard.

\section{Figure 6: Assurance by Standard}

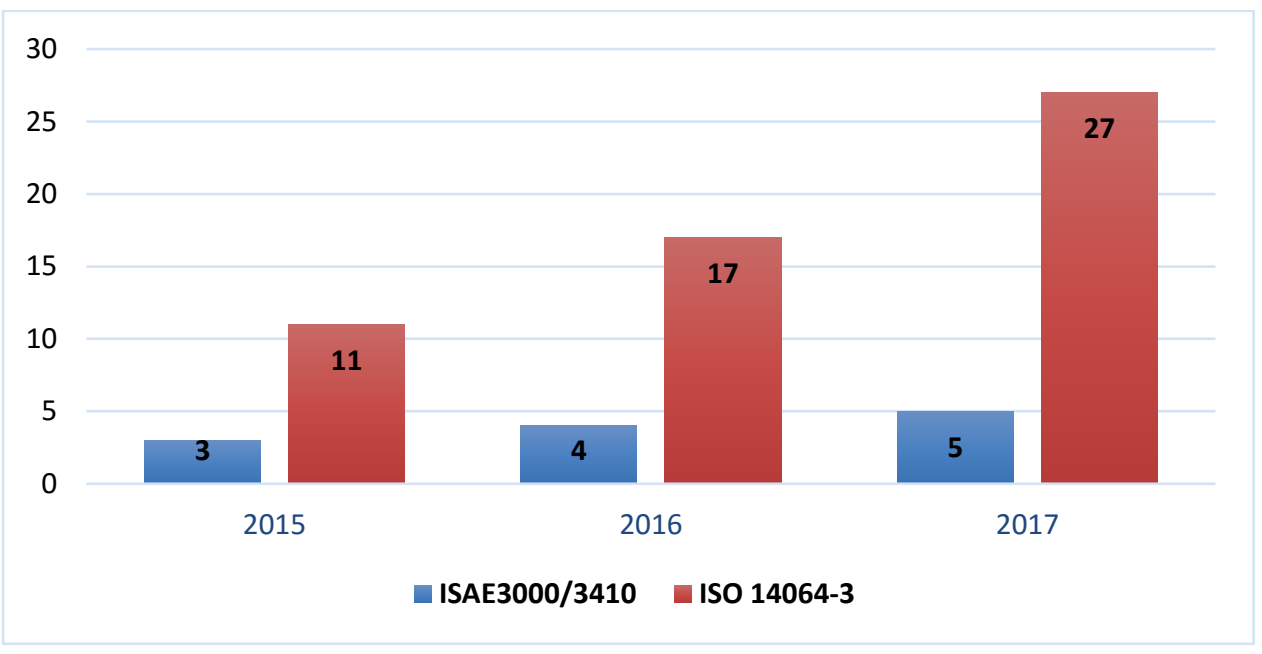

\section{CONCLUSION}

There are obvious adverse impacts of climate change on both society and compnaies all over the world. In this sense, there is an increasing trend in reporting of GHG emissions which is seen as the main factor leads to climate change. Likewise other types of reporting, decision makers need and demand reliable information. Thanks to these demands, assurance of GHG disclosures has become a necessity and both IAASB and ISO released standards dealing with this issue.

In this study, it is aimed to examine the current status of assuring practices of GHG disclosures of Turkish companies based on the data available from the Carbon Disclosure Project (CDP) Turkey surveys. Analysing these data shows that the number of companies responded to the CDP surveys increased in the period of 2015-2017. In addition, there was an increase in the number of GHG disclosures assured by third parties in the same period.

The results also reveal that Turkish companies preferred specialist providers rather than audit firms for the assurance of GHG disclosure. Furthermore, ISO14064-3 standard was predominantly preferred over the sampled period. The main reason 
behind this finding may be the fact that GHG disclosure assurance services are provided by the specialist providers mostly. Finally, we found that most assurance engagements were in the level of reasonable assurance.

Based on the results of the study, it can be said that the increasing trend in the number of companies assuring their GHG disclosures in Turkey presents opportunities for audit firms and other assurance service providers.

The study contributes to the existing literature by providing a descriptive picture of assurance practices of GHG disclosures in Turkey. As far as the authors are aware, this is the first attempt to examine the assurance of Turkish companies' GHG disclosures. Futher studies can investigate the determinants of GHG disclosure assurance in the contexts of developing and developed countries.

\section{REFERENCES}

Bastianoni, S., Marchi, M., Caro, D., Casprini, P., \& Pulselli, F. M. (2014). The connection between 2006 IPCC GHG inventory methodology and ISO 14064-1 certification standard-A reference point for the environmental policies at sub-national scale. Environmental Science \& Policy, 44, 97-107.

Beattie, V., \& Fearnley, S. (1995). The importance of audit firm characteristics and the drivers of auditor change in UK listed companies. Accounting and business research, 25(100), 227-239.

Bewley, K., \& Li, Y. (2000). Disclosure of environmental information by Canadian manufacturing companies: a voluntary disclosure perspective. Advances in environmental accounting and management, 1(1), 201-226.

Birnbaum, M. H., \& Stegner, S. E. (1979). Source credibility in social judgment: Bias, expertise, and the judge's point of view. Journal of Personality and Social Psychology, 37(1), 48.

Brink, A. G., Tang, F., \& Yang, L. (2016). The impact of estimate source and social pressure on auditors' fair value estimate choices. Behavioral Research in Accounting, 28(2), 29-40.

Chatterjee, A. (2012). Assurance of corporate greenhouse gas disclosures in the mining and crude oil production sector: a comparative international Study. Journal of the Asia-Pacific Centre for Environmental Accountability, 18(2), 75-102.

Cohen, J. R., \& Simnett, R. (2015). CSR and assurance services: A research agenda. Auditing: A Journal of Practice \& Theory, 34(1), 59-74.

Cohen, J. R., \& Simnett, R. (2015). CSR and assurance services: A research agenda. Auditing: A Journal of Practice \& Theory, 34(1), 59-74.

Cotter, J., Lokman, N., \& Najah, M. M. (2011). Voluntary disclosure research: which theory is relevant ?. Journal of Theoretical Accounting Research, 6(2) 1-25.

Datt, R., Luo, L., Tang, Q., \& Mallik, G. (2018). An international study of determinants of voluntary carbon assurance. Journal of International Accounting Research, 17(3), 1-20.

DeAngelo, L. E. (1981). Auditor size and audit quality. Journal of accounting and economics, 3(3), 183-199.

Feng, Y. \& Ramanathan, V. (2009). Air pollution, greenhouse gases and climate change: Global and regional perspectives. Atmospheric Environment, 43, 37-50.

Freedman, M., \& Jaggi, B. (2005). Global warming, commitment to the Kyoto protocol, and accounting disclosures by the largest global public firms from polluting industries. The International Journal of Accounting, 40(3), 215-232.

Gokten, P. O., Marşap, B., \& Gokten, S. (2018). Sera Gazı Emisyon Raporlaması Bir Tercih Mi Yoksa Zorunluluk Mu? Kuramsal Bir Değerlendirme. Muhasebe Bilim Dünyası Dergisi, 20, 911-922.

Green, W. \& Li, Q. (2011). Evidence of an expectation gap for greenhouse gas emissions assurance. Accounting, Auditing \& Accountability Journal, 25(1), 146-173.

Green, W., \& Li, Q. (2012). Evidence of an expectation gap for greenhouse gas emissions assurance. Accounting, Auditing \& Accountability Journal.

Green, W., \& Taylor, S. (2013). Factors that influence perceptions of greenhouse gas assurance provider quality. International Journal of Auditing, 17(3), 288-307.

Green, W., \& Zhou, S. (2013). An international examination of assurance practices on carbon emissions disclosures. Australian Accounting Review, 23(1), 54-66.

Green, W., Taylor, S., \& Wu, J. (2017). Determinants of greenhouse gas assurance provider choice. Meditari Accountancy Research. 
Guthrie, J., \& Abeysekera, I. (2006). Content analysis of social, environmental reporting: what is new?. Journal of Human Resource Costing \& Accounting.

Hahn, R., Reimsbach, D. \& Scheimann, F. (2015). Organizations, Climate Change, And Transparency: Reviewing The Literature On Carbon Disclosure. Organization \& Environment, 28(1), 80-102.

Harrison, J. S., \& Wicks, A. C. (2013). Stakeholder theory, value, and firm performance. Business Ethics Quarterly, 23(1), 97-124.

Hogarth, R. M., \& Einhorn, H. J. (1992). Order effects in belief updating: The belief-adjustment model. Cognitive psychology, $24(1), 1-55$.

Holt, T. P. (2012). The effects of internal audit role and reporting relationships on investor perceptions of disclosure credibility. Managerial Auditing Journal.

Houghton, J. (2004). Global warming: the complete briefing. 3rd Edition. New York: Cambridge University Press.

IAASB.(2019).https://www.iaasb.org/news-events/2012-06/iaasb-releases-new-global-standard-assurance-greenhouse-gas-statements [11.02.2020].

International Auditing and Assurance Standards Board (IAASB). (2015). International standard on assurance engagements 3410: Assurance engagements on greenhouse gas statements. Retrieved October 15, 2020, from http://www.ifac.org/publicationsresources/2015-handbookinternational-quality-control-auditing-review-other-assurance.

IUCN, (2011). Terminologies used in climate change. Retrieved October 05, 2020, from https://portals.iucn.org/library/sites/library/files/documents/2011-118.pdf.

Kilgore, A., Harrison, G., \& Radich, R. (2014). Audit quality: what's important to users of audit services. Managerial Auditing Journal.

Kim, S., Green, W. J., \& Johnstone, K. M. (2015). Biased evidence processing by multidisciplinary greenhouse gas assurance teams. AUDITING: A Journal of Practice \& Theory, 35(3), 119-139.

Koonce, L., Walker, N. R., \& Wright, W. F. (1993). A cognitive characterization of audit analytical review; Discussion. Auditing, $12,57$.

KPMG, (2017). The KPMG Survey of Corporate Responsibility Reporting 2017. Retrieved October 20, 2020, from https://assets.kpmg/content/dam/kpmg/be/pdf/2017/kpmg-survey-of-corporate-responsibility-reporting-2017.pdf.

Li, H., Fu, S., Chen, Z., Shi, J., Yang, Z., \& Li, Z. (2019). The motivations of Chinese firms in response to the Carbon Disclosure Project. Environmental Science and Pollution Research, 26(27), 27792-27807.

Omur, G. A., Tunc, A. O., \& Caliskan, E. N. (2012). Corporate social and environmental responsibility in the service sector: A case study from Turkey. International Journal of Business and Management Studies, 4(1), 11-20.

Pinsker, R. (2007). Long series of information and nonprofessional investors' belief revision. Behavioral Research in Accounting, 19(1), 197214.

Pornpitakpan, C. (2004). The persuasiveness of source credibility: A critical review of five decades' evidence. Journal of applied social psychology, 34(2), 243-281.

Shum, P., Burritt, R. L., \& Chen, H. (2009). Sustainability reporting and assurance in developing countries. In 1 st South American Congress on Social and Environmental Accounting Research-CSEAR 2009. Universidade Federal do Rio de Janeiro Rio de Janeiro-Brasil.

Simnett, R., \& Nugent, M. (2007). Developing an assurance standard for carbon emissions disclosures. Australian Accounting Review, 17(42), 37-47.

Zhou, S. H. A. N., Simnett, R. O. G. E. R., \& Green, W. E. N. D. Y. (2013). The effect of legal environment and corporate governance on the decision to assure and assurance provider choice: Evidence from the GHG assurance market. UNSW Australian School of Business Research Paper. A, 5.

Zhou, S., Simnett, R., \& Green, W. J. (2016). Assuring a new market: The interplay between country-level and company-level factors on the demand for greenhouse gas (GHG) information assurance and the choice of assurance provider. Auditing: A Journal of Practice \& Theory, 35(3), 141-168 


\section{APPENDIX A: Determinants of GHG Disclosure Assurance}

\begin{tabular}{|c|c|c|c|c|c|c|}
\hline \multicolumn{7}{|c|}{ Panel A- Scope of Assurance } \\
\hline & \multicolumn{2}{|c|}{ CDP2015 } & \multicolumn{2}{|c|}{ CDP2016 } & \multicolumn{2}{|c|}{ CDP2017 } \\
\hline & $\mathrm{N}$ & $\%$ & $\mathrm{~N}$ & $\%$ & $\mathrm{~N}$ & $\%$ \\
\hline GHG and Environmental Risks Information & 2 & $13 \%$ & 4 & $17 \%$ & 4 & $12 \%$ \\
\hline Standalone GHG Information & 13 & $87 \%$ & 18 & $75 \%$ & 26 & $76 \%$ \\
\hline Information not Reported & 0 & $0 \%$ & 2 & $8 \%$ & 4 & $12 \%$ \\
\hline TOTAL & 15 & $100 \%$ & 24 & $100 \%$ & 34 & $100 \%$ \\
\hline \multicolumn{7}{|c|}{ Panel B -Level of Assurance } \\
\hline & \multicolumn{2}{|c|}{ CDP2015 } & \multicolumn{2}{|c|}{ CDP2016 } & \multicolumn{2}{|c|}{ CDP2017 } \\
\hline & $\mathrm{N}$ & $\%$ & $\mathrm{~N}$ & $\%$ & $\mathrm{~N}$ & $\%$ \\
\hline High Assurance & 2 & $13 \%$ & 2 & $8 \%$ & 2 & $6 \%$ \\
\hline Reasonable Assurance & 6 & $40 \%$ & 12 & $50 \%$ & 20 & $59 \%$ \\
\hline Limited Assurance & 5 & $34 \%$ & 8 & $34 \%$ & 10 & $29 \%$ \\
\hline Third Party Verification/ Assurance Underway & 2 & $13 \%$ & 2 & $8 \%$ & 2 & $6 \%$ \\
\hline TOTAL & 15 & $100 \%$ & 24 & $100 \%$ & 34 & $100 \%$ \\
\hline \multicolumn{7}{|c|}{ Panel C- Assurance Standard } \\
\hline & \multicolumn{2}{|c|}{ CDP2015 } & \multicolumn{2}{|c|}{ CDP2016 } & \multicolumn{2}{|c|}{ CDP2017 } \\
\hline & $\mathrm{N}$ & $\%$ & $\mathrm{~N}$ & $\%$ & $\mathrm{~N}$ & $\%$ \\
\hline ISAE3000/3410 & 3 & $20 \%$ & 4 & $17 \%$ & 5 & $15 \%$ \\
\hline ISO14064-3 & 11 & $73 \%$ & 17 & $71 \%$ & 27 & $79 \%$ \\
\hline Information not Reported & 1 & $7 \%$ & 3 & $12 \%$ & 2 & $6 \%$ \\
\hline TOTAL & 15 & $100 \%$ & 24 & $100 \%$ & 34 & $100 \%$ \\
\hline
\end{tabular}

